\section{IAC Obatã 4739 - dwarf arabic coffee cultivar with yellow fruits and resistant to leaf rust}

\section{Luiz Carlos Fazuoli ${ }^{1}$, Masako Toma Braghini ${ }^{1}$, Maria Bernadete Silvarolla ${ }^{1}$, Wallace Gonçalves ${ }^{1}$, Júlio César Mistro ${ }^{1}$, Paulo Boller Gallo and Oliveiro Guerreiro Filho ${ }^{1^{*}}$}

\begin{abstract}
Cultivar IAC Obatã 4739 was derived from a cross between coffee tree IAC 1669-20-1 and cultivar Catuai Amarelo IAC 62. It is short and high-yielding, rust-resistant, has large and yellow fruits, medium to late maturation, excellent cup quality, and responds effectively to irrigation.
\end{abstract}

Key words: Coffea arabica, cup quality, Hemileia vastatrix.

\section{INTRODUCTION}

Production cost is one of the most decisive factors for the competitiveness of Brazilian coffee. The magnitude varies according to the cultivation region, level of technological practices and crop management, but particularly the cultivars, which are largely susceptible to coffee rust, caused by the fungus Hemileia vastatrix, the main coffee disease in Brazil.

The development of rust-resistant cultivars is one of the most urgent targets of coffee breeding programs, since the genetic diversity related to the pathogenicity observed in Hemileia vastatrix species on coffee trees in Brazil is very high.

Cultivar IAC Obatã 4739, selected by the Agronomic Institute of Campinas (IAC), is a new option for coffee producers. Its fruits are large and yellow, the trees very productive and resistant to several fungus races occurring in Brazil, mainly the races I, II, III, X, XV, XVII, XXIII, and XXIV that infect Coffea arabica, as well as race XXII, isolated from coffee progenies of Híbrido de Timor CIFC $832 / 2$. Other morphological, technological and agronomic characteristics of this cultivar are described below.

\section{BREEDING PROCESS}

Cultivar IAC Obatã 4739 was derived in 1983 from a natural cross between the coffee tree IAC 1669-20-1 C 16B, in the $\mathrm{F}_{1} \mathrm{RC}$, generation and cultivar Catuaí Amarelo IAC 62, both participants in the progeny test EP 289, established in Garça, SP (Fazuoli et al. 2007).

The experiment was installed with the planting of two seedlings per pit, labelled A and B. Seeds of red-colored fruits of plant B of pit 16 , of the coffee tree IAC 1669-20-1, harvested in 1984, were sown and the seedlings grown for planting in a field experiment with the $F_{1} R C_{2}$ generation, in the same year. Seeds of coffee trees of this generation, planted in Garça, SP, with orange fruits, were
Crop Breeding and Applied Biotechnology 18: 330-333, 2018 Brazilian Society of Plant Breeding. Printed in Brazil http://dx.doi.org/10.1590/1984$70332018 v 18 n 3 c 49$

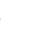
ti 
used to establish seedlings for planting of the $\mathrm{F}_{2} \mathrm{RC}_{2}$ generation in two municipalities of the state of São Paulo (Garça and Ribeirão Corrente). In these different experiments, the best coffee trees were selected and plants with yellow fruits and similar agronomic characteristics to those of red-fruit cultivar Obatã IAC 1669-20 were selected. The generations of the yellow-fruit trees of IAC 1669-20-1 were advanced at an experimental station of the Instituto Agronômico de Campinas (IAC), in Mococa, SP, at the Polo Regional Nordeste Paulista - APTA, on the farm Fazenda da Mata, in Garça, SP, on the farms Monte Alegre and Água Limpa, in Ribeirão Corrente, SP, and on the Fazenda Capoerinha, in Alfenas, Minas Gerais (MG). At the IAC Experimental Center in Campinas, selection was initiated in 2001, with coffee trees of the $F_{5} R_{2}$ generation. Thus, several generations were subjected to selection, using the genealogical method. The population of selected yellow-fruit coffee trees in the $\mathrm{F}_{7} \mathrm{RC}_{2}$ generation with rust resistance was designated IAC Obatã 4739 (Figure 1).

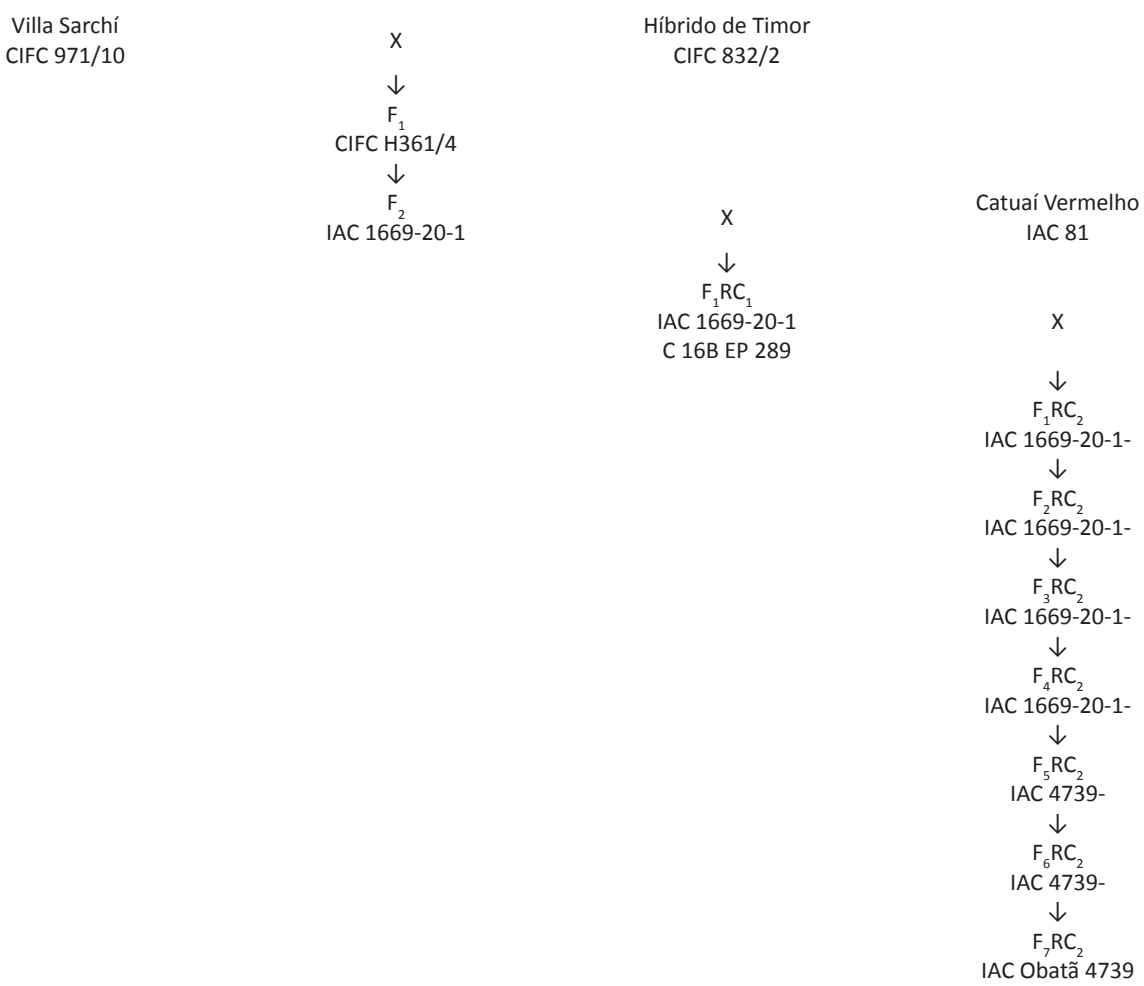

Figure 1. Genealogy of the Coffea arabica cultivar IAC Obatã 4739.

Catuaí Amarelo IAC 62 EP 289

\section{PERFORMANCE}

Cultivar IAC Obatã 4739 was evaluated in rainfed and irrigated field experiments, in regions suited for $C$. arabica cultivation in the states of São Paulo and Minas Gerais. The results related to the mean yield of the cultivar in bags of green coffee ha $^{-1}$ year $^{-1}$ are listed in Table 1. Differences were observed in growth and yield of the trees of cultivar IAC Obatã 4739, between rainfed and irrigated management of the cultivars used as controls.

In the irrigated area, in Gália, SP, the mean yield of five harvests of cultivar IAC Obatã 4739 was 83.2 bags of green coffee ha ${ }^{-1}$ year $^{-1}$, while the experimental control cultivar Catuaí Amarelo IAC 62 produced 59.4 bags of green coffee ha $^{-1}$ year $^{-1}$.

In rainfed areas, the mean yield of cultivar IAC Obatã 4739 ranged from 28.7 to 60 bags of green coffee ha-1 year $^{-1}$, while the means of Catuaí Vermelho IAC 24, Catuaí Vermelho IAC 99, Catuaí Amarelo IAC 17, and Catuaí Amarelo IAC 62 , used as control in eight experiments, ranged from 32.0 to 40.0 bags of green coffee ha-1 year $^{-1}$. 


\section{LC Fazuoli et al.}

Based on the experimental results, cultivar IAC Obatã 4739 is recommended for planting in areas suited for arabica coffee cultivation, mainly in areas without severe drought. The cultivar should preferably be planted in irrigated areas.

\section{OTHER TRAITS}

The yellow fruits of cultivar IAC Obatã 4739 are a consequence of the homozygotic expression of the allele $x c$ (xanthocarpa) (Krug and Carvalho 1940), representing the main difference in relation to red-fruit cultivar Obatã IAC 1669-20 (Bettencourt and Fazuoli 2008). The maturation of the fruits of cultivar IAC Obatã 4739 is medium to late and, in some regions, later than that of cultivar Catuaí Amarelo IAC 62. It has short compact plants, short internodes, broad and green leaves when young, and large fruits. The canopy height and diameter are similar to those of cultivar Catuaí Amarelo IAC 62. The percentage of normal flat beans is higher than $85 \%$ and the mean bean size around 17. The output, i.e., the relation of the green to dry coffee weight, is close to $50 \%$.

The cultivar is resistant to the coffee rust races I, II, III, X, XV, XVII, XXII, XXIII, and XXIV, caused by H. vastatrix, susceptible to coffee-leaf miner Leucoptera coffeella, coffee berry borer Hypothenemus hampei and brown-eye spot disease Cercospora coffeicola. Resistance to coffee rust allows cultivation without fungicide application and may have a reducing impact on crop production costs and the risk of environmental pollution.

Sensory analyses carried out in 2015 and 2016 in Patrocínio, MG, using the SCAA protocol (Lingle 2001), revealed the excellent cup quality of this cultivar, similar to that of the red-fruit cultivar Obatã IAC 1669-20 and of cultivar Catuaí Amarelo IAC 17, both used as experimental controls in the tests (Table 2).

The participation of cultivar Bourbon in the development of cultivar IAC Obatã 4739 is estimated at around $68.8 \%$. Its other morphological, technological and agronomic characteristics are listed in Table 3.

\section{SEED MAINTENANCE AND DISTRIBUTION}

Cultivar IAC Obatã 4739 was registered by the IAC in the National Cultivar Registry (Registro Nacional de Cultivares - RNC) on 12/18/2012 (Register No. 30009) and protected by the National Cultivar Protection Service (Serviço Nacional de Proteção de Cultivares - SNPC) on November 7, 2014 (Certificate No. 20150080). During the

Table 1. Mean yield of bags of green coffee ha-1 year $^{-1}$ of cultivar IAC Obatã 4739, under irrigated and rainfed conditions.

\begin{tabular}{lccc}
\hline \multirow{2}{*}{ Location } & \multirow{2}{*}{ Harvest } & \multicolumn{2}{c}{ Cultivar } \\
\cline { 3 - 4 } & & & \\
\hline Irrigated & & & \\
$\quad$ Gália, SP & 5 & & 59.2 \\
Rainfed & & 28.7 & $32.4^{1}$ \\
$\quad$ Garça, SP & 3 & 33.8 & $32.3^{2}$ \\
Mococa, SP & 8 & 49.7 & $35.2^{1}$ \\
Mococa, SP & 2 & 37.5 & $36.4^{1}$ \\
Garça, SP & 6 & 60.0 & $38.8^{1}$ \\
Campinas, SP & 3 & 45.0 & $40.0^{1}$ \\
$\quad$ Ribeirão Corrente, SP & 4 & 50.1 & $36.5^{3}$ \\
$\quad$ Franca, SP & 7 & 55.8 & $32.1^{4}$ \\
Patrocínio, MG & 4 & &
\end{tabular}

Table 2. Overall quality, in scores, according to the cupping protocol of the Specialty Coffee Association of America (SCAA), acidity, body and flavor-taste properties of the cup quality of the cultivars IAC Obatã 4739, Obatã IAC 1669-20, and Catuaí Amarelo IAC 17

\begin{tabular}{|c|c|c|c|c|}
\hline Trait & Harvest & IAC Obatã 4739 & Obatã IAC 1669-20 & Catuaí Amarelo IAC 17 \\
\hline \multirow{2}{*}{ Overall quality (scores) } & 2015 & 82.5 & 81.5 & 82.5 \\
\hline & 2016 & 83.0 & 83.0 & 85.0 \\
\hline \multirow{2}{*}{ Acidity } & 2015 & Medium & High & High \\
\hline & 2016 & Medium & Medium & Medium \\
\hline Body & 2016 & Medium & Medium & High \\
\hline \multirow{2}{*}{ Flavor-taste properties } & 2015 & $\begin{array}{l}\text { Nuts, stone fruit, choco- } \\
\text { late, caramel }\end{array}$ & $\begin{array}{l}\text { Chestnut, stone fruit, cara- } \\
\text { mel, chocolate }\end{array}$ & Nuts, stone fruit, chocolate, caramel \\
\hline & 2016 & $\begin{array}{l}\text { Nuts, dry fruit, chocolate, } \\
\text { caramel }\end{array}$ & $\begin{array}{l}\text { Nuts, citrus fruit, chocolate, } \\
\text { caramel }\end{array}$ & $\begin{array}{l}\text { Floral, chestnut, stone fruit, choco- } \\
\text { late, caramel, sweet, silky, creamy }\end{array}$ \\
\hline
\end{tabular}


IAC Obatã 4739 - dwarf arabic coffee cultivar with yellow fruits and resistant to leaf rust

Table 3. Morphological, technological and agronomic traits of cultivar IAC Obatã 4739 with the respective descriptions

\begin{tabular}{|c|c|}
\hline Trait & Description $^{1}$ \\
\hline Size (tree height) & Small (Catuaí) \\
\hline Canopy radius & Small (Catuaí) \\
\hline Canopy architecture & Cylindrical (Catuaí) \\
\hline Internode length & Short (Catuaí) \\
\hline Intensity plagiotropic branching & Between medium (Mundo Novo) and high ( Catuaí) \\
\hline Young leaf color & Green (Catuaí) \\
\hline Leaf shape & Oval \\
\hline Undulation of the leaf margin & Medium wavy (Mundo Novo) \\
\hline Color of ripe fruits & Yellow \\
\hline Fruit shape & Oblong (Mundo Novo) \\
\hline Fruit size & Between medium (Mundo Novo) and large (Acaiá) \\
\hline Resistance to rust ${ }^{2}$ & Resistant \\
\hline Resistance to nematodes & Susceptible \\
\hline Reaction to brown eye spot ${ }^{3}$ & Susceptible \\
\hline Cup quality & Similar to Catuaí Amarelo and Obatã IAC 1669-20 \\
\hline
\end{tabular}

${ }^{1}$ Catuaí, Mundo Novo, Obatã IAC 1669-20 and Acaiá are Brazilian cultivars of Coffea arabica; ${ }^{2}$ Hemileia vastatrix Berkeley \& Broome; ${ }^{3}$ Cercospora coffeicola Berkeley \& Cooke.

experimental phase, cultivar IAC Obatã 4739 was designated Obatã Amarelo IAC 4739, the name that appears in the documents of cultivar protection. The IAC and APTA Polo Regional Nordeste Paulista are responsible for the production and distribution of genetic seeds.

\section{ACKNOWLEDGEMENTS}

The authors are grateful to the Consórcio Brasileiro de Pesquisa e Desenvolvimento do Café (CBP\&D/Café) for financial support and a research scholarship to LCF and MTB, and indebted to the National Council for Scientific and Technological Development (CNPq) for a research scholarship to OGF (CNPq DT 308.634/2016-0).

\section{REFERENCES}

Bettencourt AJ and Fazuoli LC (2008) Melhoramento genético de Coffea arabica L. Transferência de genes de resistência a Hemileia vastatrix do Híbrido de Timor para a cultivar Villa Sarchí de Coffea arabica. IAC, Campinas, 20p. (Documentos IAC, 84).

Fazuoli LC, Silvarolla MB, Salva TJG, Guerreiro Filho O, Medina Filho HP and
Gonçalves W (2007) Cultivares de café arábica do IAC: Um patrimônio da cafeicultura brasileira. O Agronômico 59: 12-15.

Krug CA and Carvalho A (1940) Genética de Coffea III. Hereditariedade da cor amarela dos frutos. IAC, Campinas, 16p. (Boletim Técnico 82).

Lingle TR (2001) The coffee cuppers' handbook: systematic guide to the sensory evaluation of coffee's flavor. Specialty Coffee Association of America, Long Beach, 47p. \begin{tabular}{l}
\hline This is an Open Access article distributed under the terms of the Creative Commons Attribution License, which permits unrestricted \\
use, distribution, and reproduction in any medium, provided the original work is properly cited.
\end{tabular} 